\title{
The FOMC in 1981: Monetary Control in a Changing Financial Environment
}

\author{
DANIEL L. THORNTON
}

I AST year marked the second full year of the Federal Reserve's implementation of operating procedures introduced on October 6, 1979. Since then, the Federal Reserve has attempted to achieve better control of the growth of the monetary aggregates by placing more emphas is on controlling the growth of bank reserves and less on controlling short-rum movements in the federal funds rate. ${ }^{1}$

This past year was a turbulent one for both the economy and the conduct of monetary policy. Real GNP declined markedly in the fourth quarter after increasing rapidly during the first quarter and holding steady during the middle two quarters. The growth rates of the monetary aggregates diverged over the year, with the narrower aggregates growing at a substantially reduced pace compared with the previous year, while the broader aggregates grew somewhat more rapidly than they did the previous year.

The policy of the Federal Open Market Committee (hereafter refered to as Committee or FOMC) in 1981 reflects a commitment to restrain the growth of the monetary aggregates. A number of financial innovations and regulatory changes, however, caused the Committee to change the policy weights placed on the various monetary aggregates. Furthemore, the nationwide introduction of NOW accounts prompted

Note: Citations refered to as "Record" are to the "Record of Policy Actions of the Federal Open Market Committee" found in various issues of the Foderal Resere Bullotin.

For adescription of the current operating procedure, see R. Alon Gibert and Michael Trebing, "The FOMC in 1980 ; A Year of Reserve Tarteting," this Retiew (Augut/September 1981), pp. 222; and Richard W. Lang. "The FOMC in 1979: nutroducing heserve Targeting," this Reciow Warch 1980\}, pp. 2225. the FOMC to introduce a new monetary aggregate, shift-adjusted MIB, which it used to specify its policy directives.

This article discusses the FOMC's monetary policy decisions during 1981. The organization is as follows: The financial innovations and regulatory changes of 1981 are reviewed, and the impact of these changes on the growth rates of the various monetary aggregates is discussed. Next, the amnual policy objectives of the FOMC for the growth of various monetary aggregates are reviewed, and the actual growth rates for the year are compared with the annual targets. Finally, the short-run policy directives of the FOMC are reviewed.

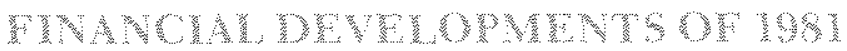

Several financial developments affected the direc. tion of monetary policy in 1981. The most important of these were the nationwide introduction of NOW accounts on January 1 , the liberalization of interest rate ceilings on small-savers certificates on August 1 , the introduction of tax-exempt All-Savers Certificates on October 1 , and the rapid, albeit varied, growth in money market mutual funds (MMMFs).

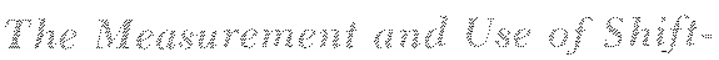 A}

The firs of these developments resulted in the use of shift-adjusted MLB for policy purposes. The FOMC had anticipated that the introduction of NOW accounts would produce a shift in the public's holding offinaneial assets, from non-demand deposit 
assets, such as savings deposits, into NOW accounts (see table 1 for the composition of the monetary aggregates), ${ }^{2}$ As a result of this shift, the FOMC anticipated that measured MlB would contain a certain amount of "hidden savings." Furthermore, until complete, this shift would cause the growth rate of measured $\mathrm{M} \perp \mathrm{B}$ to overstate the actual growth rate in transactions balances.

Initially, it was estimated that this shift would cause the growth in measured MIB to overstate the growth in transactions balances by 2 to 3 percentage points. In anticipation of this development, the Committee stated both its long-run and short-rum policy directives in tems of shift-adjusted M1B. Shift-adjusted MIB was obtained by subtracting from measured $\mathrm{MIB}$, the estimated increase in other checkable deposits (above some expected normal growth) that came from sources other than demand deposits. ${ }^{4}$

Furthermore, the FOMC anticipated that nearly all of the shift into NOW accounts from sources other than demand deposits would come from sources in-

${ }^{2}$ For a more detalled disctssion of the composition of the mone tary aggregates, see R. W. Hafer, "The New Monetary Aggregates," this Review (February 1980), pp. 25-31.

3t was assumed that individuals would shift assets primarily out of traditional demand deposits and other interest-eaming assets included in $\mathrm{M} 2$ into NOW accomts. Thus, the grow the nates of M2 and M3 would be maffected by these shifts. There were two reasons for anticipating shifts out of savings deposits into NOW acounts: First, most NoW accounts had substantial minimumbalance requirements. Thus, it was assumed that ind viduals would shift part of their savings into NOW acoounts to neet these requirements. Second, the New Fngland experience with NOW accounts indicated that about one third of the fow into ATS and NoW accounts had come from savings deposits. See "Mone" tary Policy Objectives for $1981^{\text {" }}$ "Board of Govemors of the Fedenal Reserve System, 1981), p. 4-5; and "Monetary Report to the Congress," Federal Reserve Bulletin (March 1981), pp. $195-208$.

${ }^{4}$ The proportion of the increase in other checkable deposits (OCD) that was estimated to have been shifted from sources other than demand deposits was detemined from a number of surveys and a cross sectional econometric study. It was estimated that the proportion of OCD diverted from somes other than demand deposits was beween 20-25 percent in January, and 25-30 percent thereafter. Shift-adjusted MIB was obtained by first estimating the proporion of the change in seasonally unadjusted OCD from end of the year 1980 , above some trend growth in OCD that came from soures other than demind deposits. The propontion was assumed to be the midpoint of the above ranges. Next this amount was seasonally atjusted using the seasonal factors for commercial bank savings deposits. This seasonally adiasted amomnt was then subtracted from seasonally adjusted MiB to obtain seasonally adusted, shiftadiusted MIB. For more details, see "Recent Revisions in the Money Stock," Federal Reserce Bulletin (July 1981), pp. 539-42: and John A Tatom, "Recent Financial Innovations: Have They Distorted the Meaning of M1P" this Review (April 1982), p. 23-35.

Later in the year, it appeared that most of the shift out of
Table 1

\section{Composition of Monetary Aggregates}

\begin{tabular}{|c|c|c|c|}
\hline Conponent & W/s & $\sqrt{2}$ & M3 \\
\hline Curvency & 8 & Y & $\times$ \\
\hline $\begin{array}{l}\text { At commercial banks and thritt } \\
\text { instifutions? }\end{array}$ & & & \\
\hline 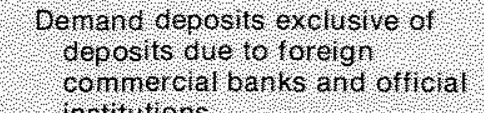 & $y$ & $y$ & $\%$ \\
\hline Now acrounts & X & $x$ & 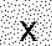 \\
\hline ATS accounts & $x$ & x & 8 \\
\hline Gredi unuon share oraft balances & $x$ & $x$ & $x$ \\
\hline 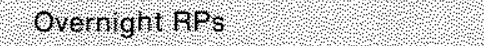 & & 8 & $x$ \\
\hline Sovings deposils ?.? ?Y? & & $x$ & $x$ \\
\hline Strall ine deposits ( S 100,000 ? & & 1 & $x$ \\
\hline Tlarge lime ceposits & & & $x$ \\
\hline Term RPs & & & \& \\
\hline fletall PPs $(8100000)$ & & x & 8 \\
\hline 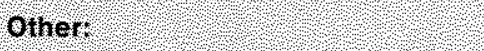 & & & \\
\hline Travelers cheolss of nombank & $x$ & $x$ & 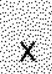 \\
\hline 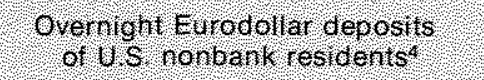 & & $x$ & $x$ \\
\hline 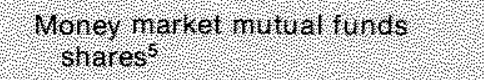 & & x & ? \\
\hline bankers acceptanses & & & $x$ \\
\hline Gontrercial papers & & & 8 \\
\hline US. savings bonds? ?? & & & $x$ \\
\hline liquild Treasury securities? & & ?: & X \\
\hline M2 consolidation conponente & & $x$ & $\mathrm{x}$ \\
\hline
\end{tabular}

The $/ 116$ series las been renamed M1 The MI seres now contains an M1 consolidalion component which reptesents the estimated portion of hilt institution vaut cash used to serice then other checkable deposit lablines.

2holades small savers cerlifcates and All Savers certhcates.

3Travelers checks were nolldod in the monetary agorecates duing the June 1981 revisions See the Board 416 rewase tor lune 26,1981

Sovernight Eurodollars issued by Caribbean brahches of nember bakks

SM2 now excludes instiution only MMMFs (funds which do not ofter accounts to indviduals) See the Boards 16 re: ease for February 5,1082 , or details:

Gepresents the estmated amount of demand deposits and vaul cash held by thrit hastitutions to service the and savings deposits.

demand and nondemand deposit components of $\mathrm{M} 2$ appeared to have taken place during the first four months of the vear. As a restat of the completion of the major portion of the shift, the Federal Reserve Board discontinued iss series on shiftadiasted M1B, effective January 6,1982 . The MlA measure was dropped at the same time. 
cluded in M2. This would cause the growth rate of measured $\mathrm{M} 1 \mathrm{~B}$ to increase relative to $\mathrm{M} 2$. However, the Committee was uncertain about the extent of the shift and about the ultimate source of the new NOW accounts. Hence, it was uncertain about the appropriate weighting of shift-adjusted M1B and M2 for policy parposes. This uncertainty was exacerbated by the rapid and varied growth of the money market mutual fund component of $\mathrm{M} 2$ during the year. ${ }^{5}$

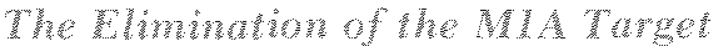

The shift from non-interest-bearing checking accounts into interest-bearing NOW accounts resulted in a substantial reduction in the growth rate of M1A (currency plus demand deposits at commercial banks). This blurred its meaning, as the proportion of checkable deposits it represented declined markedly after the first of the year. As a result, the Committee eliminated any reference to the M1A measure from its short-run policy objectives and from its tentative long-rum policy objectives for 1982.6

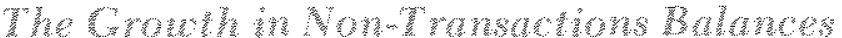

It was believed that the liberalization of interest rate ceilings on small-savers certificates and the introduction of tax-exempt All-Savers Certificates would increase the attractiveness of these com. ponents of $\mathrm{M} 2$ relative to money market assets that are not included in M2. By the middle of 1981, the Committee was concerned that these regulatory changes, especially the introduction of All-Savers Certificates, would produce shifts from money market assets into these components of $\mathrm{M} 2$. The Committee believed that these changes might cause a rapid acceleration in the growth rate of $\mathrm{M} 2$, especially during the fourth quarter of the year, altering the relative growth rates of $\mathrm{M} 2$ and shift-adjusted MlB still further. Thus, these regulatory changes also contributed to the uncertainty about the appropriate weighting of shift-adjusted $\mathrm{M} 1 \mathrm{~B}$ and $\mathrm{M} 2$.

This uncertainty was heightened by the increase in the income velocity of shift-adjusted M1B during

5See "Record" (April 1981), p. 314; and "Recond" June 1981), p. $500 \mathrm{~m}$.

The Commitee decided to omit reference to MlA from its statement of the short-rum policy objectives for 198 at the March meeting and from its statement of long-run policy directives for 1981-82 at the July neeting. See "Record" (June 1981), p. 500; and "Record" (September 1981), p. 716. the year. ${ }^{7}$ It was argued that high interest rates had induced the use of new cash management techniques that reduced the demand for traditional transactions balances, thus increasing the income velocity of money. For example, it was argued that since many MMMFs have check-writing privileges, they nay themselves be considered transactions balances, or at least close substitutes for the transactions balances included in M1B. If this were true, shift-adjusted MIB would understate the growth in transactions balances of the economy.

\section{ANNUAL TARGTS TOR 1981}

The Full Employment and Balance Growth Act of 1978 (also called the Humphrey-Hawkins Act) requires the Board of Governors, each February and July, to transmit to Congress reports on the objectives for growth rate ranges for monetary and credit aggregates over the current calendar year and, in the case of the July report, the objectives for the following calendar year as well. The Committee has chosen to establish ranges from the fourth quarter of the previous year to the fourth quarter of the current year. ${ }^{8}$ While these ranges must be reported to Congress each February and July, the Act provides that the Board and the Committee may reconsider the annual ranges at any time. ${ }^{9}$ The period to which the annual ranges apply, however, may not be changed. The base period (the fouth quarter of the previous year) would remain the same even if the Committee decided to change the desired growth rates of the aggregates for the year.

At its February meeting, the Committee agreed on the desirability of reducing the rate of monetary growth, thereby contributing to reducing the in-

"See "Record" (July 1981), p, 568. The income velocity of money is given by the ratio of nominal GNP to money. It indicates the number of times each mit of nominal money "tums over" in producing this year's final output.

"Prom to 1979 , the Committee adopted one-year growth rates each quater, and the base period for the anmual targets announced each quarter was brought forward to the most recent quarter. This method resulted in a problem referred to as "base drift." Growth in argregates above (below) at annual growth range in a quarter would rase (lower) the base level for calculating the next annal growth path. Spectication of annual objectives in terms of calendar year growth rates, which eliminates the base drift problen within a calendar vear, does not solve this problem from one calendar year to the next, since new ranges are established from the end of each calendir year.

9 At its midyear review of the ammal ranges, the Committec also atablished tentative ranges for the monetary aggregates for the next year - measured from the fourth quater of the current year to the fourth quarter of the following year. 
flation rate and providing a basis for economic stability and sustainable growth in GNP.10 The Committee agreed to specify an annual target range for shift-adjusted M1B that was $1 / 2$ percentage point below the comparable range for 1980.11 There was less agreement, however, on the specification of the grow th rate ranges for the broader monetary aggregates.

Members difered somewhat more in their views concerung the broader monetary aggregates, in part becaze of uncertainty about the potential effects of interest rate relationships on the behavior of the nontransaction component. Reflecting an expectation that growth of the broader aggregates would increase relative to that of the narrow aggregates adjusted for expansion of NOW acconnts, a number of members favored specification of ranges slightly higher than those for 1980. However, most members believed that sufficient allowance for the possibility of relatively stronger growth of the broader aggregates would be made by reiterating the 1980 ranges for them in association with ranges for the namower atggregates that were $1 / 2$ percentage point lower than those for 1980 . In this connection, it was stressed that specification of anges rather than precise rates for growth over the year inherently provided for some change in relative ates of growth among the monem lary aggregates, and that growth of both $\mathrm{M} 2$ and $\mathrm{M}, 3$ might well be in the upper portions of thetr ranges. Even so, growth of the broader aggregates would be less than actual growth in 1980 . One member preferred to focus exclusively on the narrower aggregates, not specifying ranges for the broader aggregates. ${ }^{22}$

At the end of this discussion, the Committee established the same anmual target ranges for M2 and M3 as it had established in 1980 . Table 2 shows the target growth rates for shift-adjusted M1B, M2 and M3 that the Committee established at its February meeting. ${ }^{13}$ The Committee did not establish annual grow th rate ranges for measured MLB. However, it Was estimated that a range of 6 to $81 / 2$ percent for measured M $1 \mathrm{~B}$ would correspond to the Committee's range for shift-adjusted M $1 B .{ }^{14}$ Growth rates of the monetary aggregates relative to their long-run ranges are presented in charts 1 and 2 .

\footnotetext{
10."Record" (April 1981), p. 315.

${ }^{19}$ There was no shift adjustment to MIB in 1980. Thus, the "comparable range" is the 1980 range for actual MiB.

12"Record" (April 1981), p. 315.

${ }^{13}$ "Record" (April 1981), p. 316; and "Monetary Report to Congress" p. 205. An ambual target range for Ml A was adopted at the February meeting (3-5/2 percent). It is not reported here, however, because MIA was dropped for policy considerations later in the year. See footnote 6 .

$13^{\prime \prime}$ Monetary Report to Congress," p. 207.
}

\section{Table 2}

Planned Growth of Monetary Aggregates for 1981 (percent changes, fourth quarter to fourth quarter)

\begin{tabular}{|c|c|c|c|}
\hline s & $\begin{array}{l}\text { proposed } \\
\text { range tor } \\
1981\end{array}$ & $\begin{array}{l}\text { Actual } \\
\text { growtr } \\
\text { rase }\end{array}$ & $\begin{array}{l}\text { Actual } \\
1981 \\
\text { growth } \\
\text { rate }\end{array}$ \\
\hline 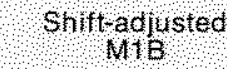 & उ $-5,0 \%$ & $66^{\circ}$ & 2,30 \\
\hline 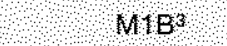 & $6,0,85 \mathrm{~s}$ & 73 & 50 \\
\hline & $6 0 \longdiv { 9 0 }$ & 92 & 94 \\
\hline $\mathrm{Mr}$ & 65,95 & 100 & 114 \\
\hline \multicolumn{4}{|c|}{ 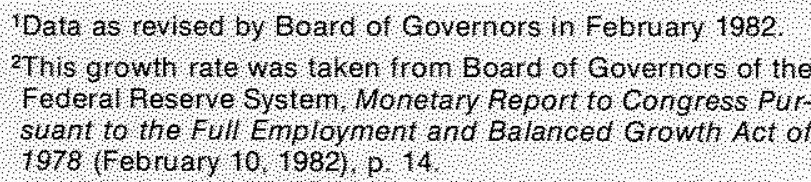 } \\
\hline \multicolumn{4}{|c|}{ 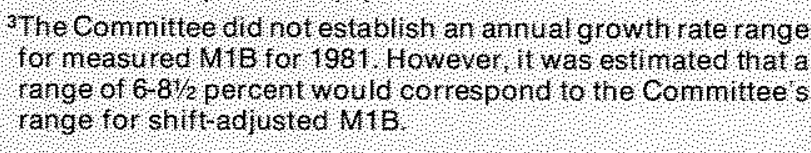 } \\
\hline
\end{tabular}

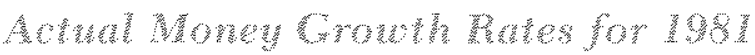

As shown in table 2 , the broader monetary aggrew gates grew at rates above their long-run ranges for the year: $M 2$ grew at a 9.4 percent rate, just above the top of its range, while M3 grew at a 11.4 percent rate, 2 percentage points above the top of its annual mange.

In contrast, the growth rate of shift-adjusted MIB was substantially below its target range for 1981 . Shiftadjusted M1B grew at an anmual rate of 2.3 percent from the fourth quarter of 1980 to the fourth quarter of 1981 , about 1 percentage point below the lower end of its planned growth range. ${ }^{15}$

While this shortfall in the growth of shift-adjusted MLB was somewhat larger than the Committee anticipated by mid-year, financial developments during the year led it to aceept a slower growth in shift-adjusted MIB as long as the growth in the broader monetary aggregates remained at the upper ends of their ranges.

... in light of its desire to maintain moderate growth in money over the balance of the year, the Committee wished to affinn that growth in MlB near the lower

\footnotetext{
${ }^{15}$ Because there was no shift-adjusted M $1 \mathrm{~B}$ for the fouth quarter of 1980 , its growth rate was calculated from the average level of MIB for the fourth quarter of 1980.
} 
Chart 1

\section{MIB, Shift-Adjusted MIB and Growth Objectives for Shift-Adjusted MIB}

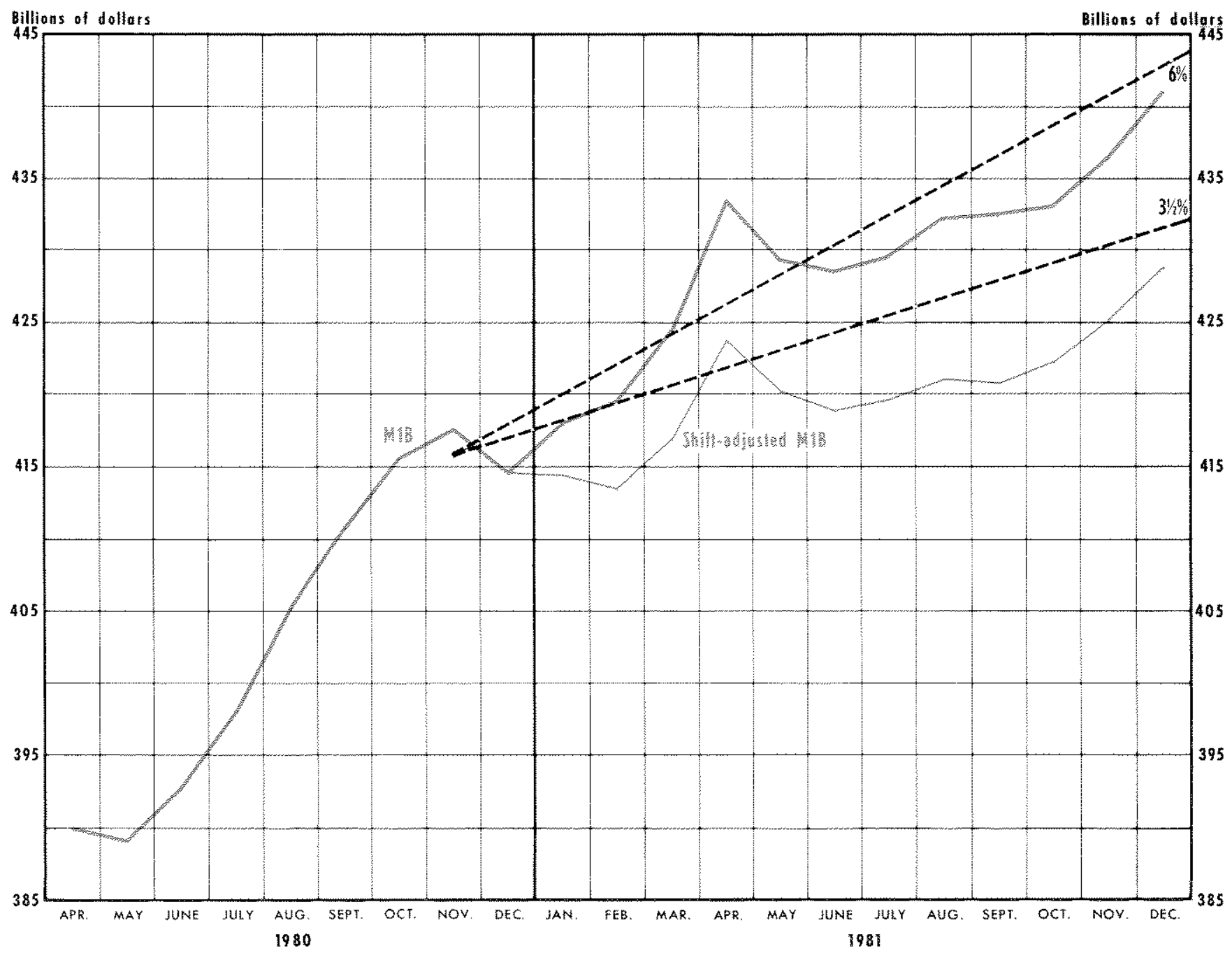

end of its range would be accentable and desirable. At the same lime, the Committes recognized that grow th in the broader monetary aggregates might be high in their ranges (italios added). ${ }^{16}$

Much of the willingness to accept a slower rate of growth in shift-adjusted MIB stemmed from uncertainty about the extent to which financial developments were affecting the relative growth rates of

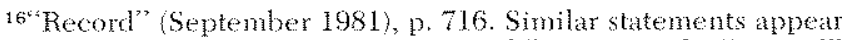
on mumerous occasions in the "Record." For example, "Record" (October 1981), p. 792 and 794; (December 1981), p. 908; and Gamuary 1982), p. 41. Also, see "Statement by Patal A. Voleker, Chamman, Bont of Goremors of the Federal Reserve System, before the Committee on Banking, Finance and Utban Affaiss,"

Federal Pesere Bulletin (Augnst 1981), D. 615. various monetary aggregates, and the extent to which these developments in tum were affecting the relationship between the aggregates and economic activity. This is most evident in the Committee's discussion of short-run policy directives for 1981 .

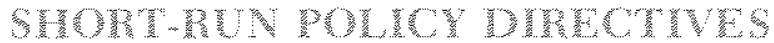 Mon 198}

The announcement of annual target ranges for the monetary aggregates, mandated by the Full Employment and Balanced Growth Act of 1978, is intended to set public guidelines for the FOMC in choosing short-rum policy objectives during the year. Committee decisions that influence the daty-torday 
Chart 2

Ranges for M2 and M3 for Period IV /80 to IV/81

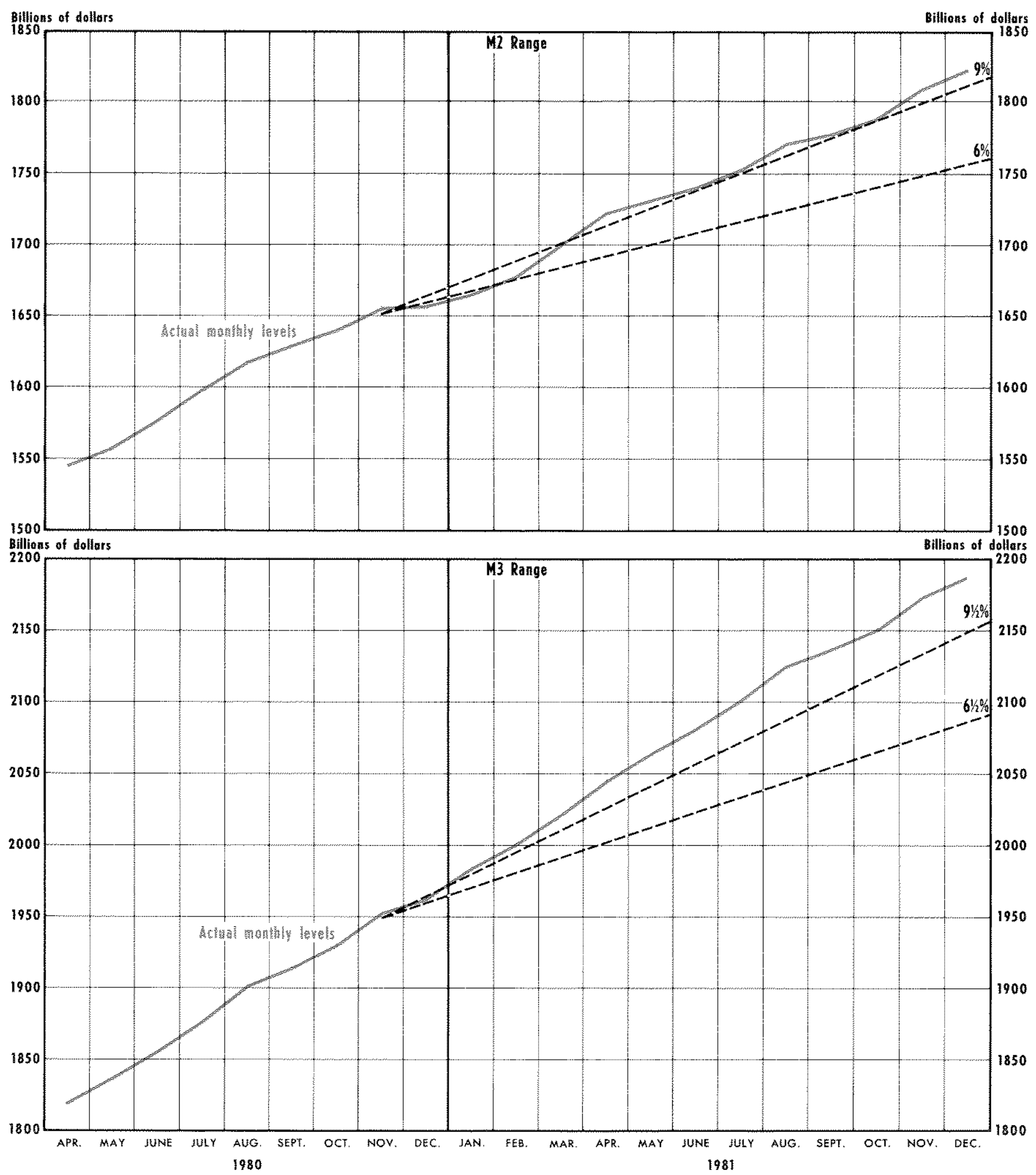




\section{Chart 3}

\section{FOMC Ranges for Federal Funds Rate}

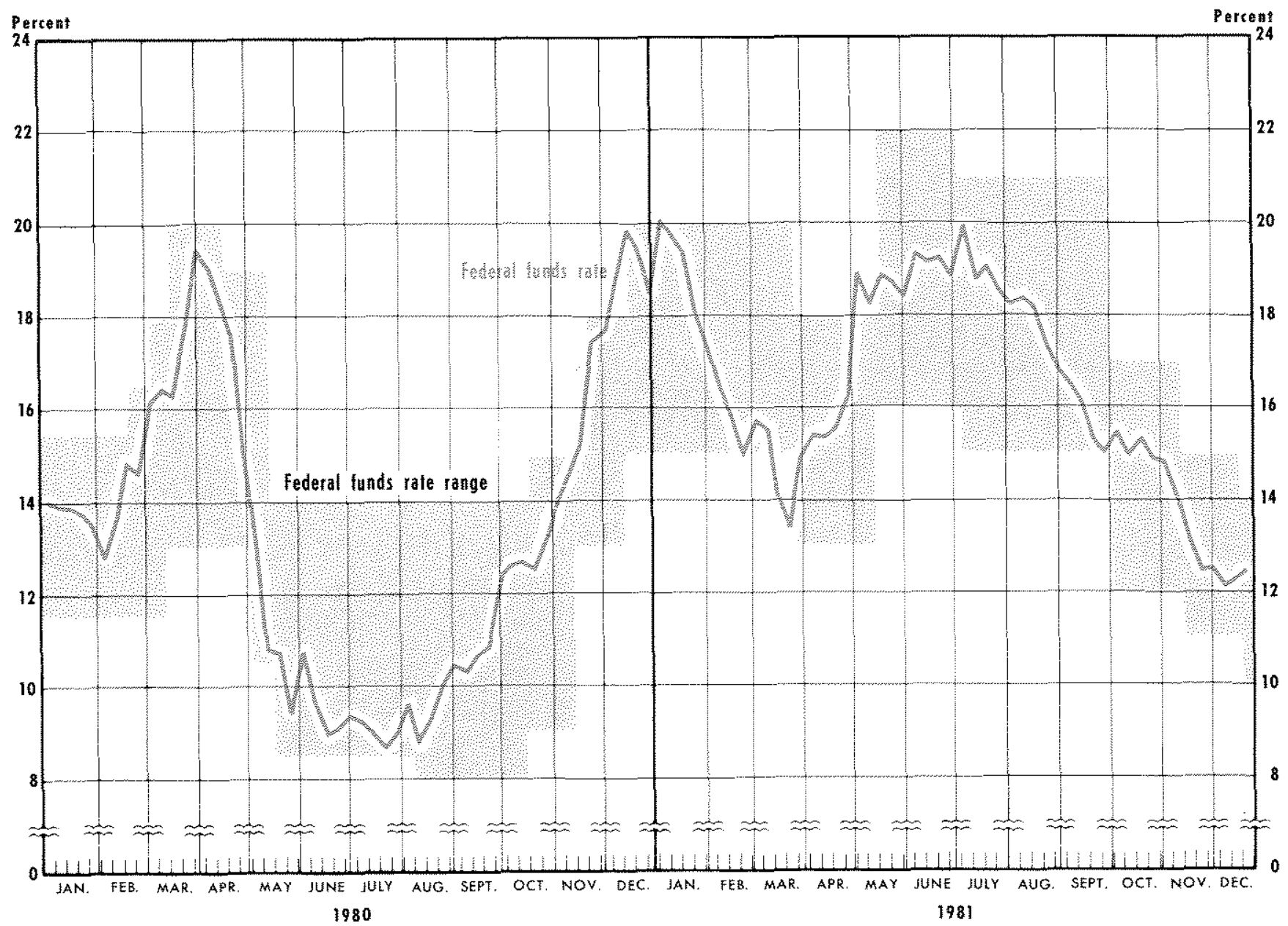

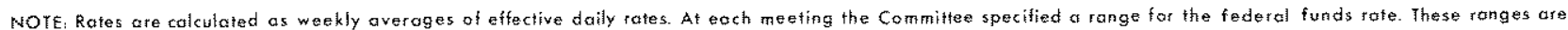
indicated for the firs! full week during which they were in effect

implementation of monetary policy, however, are specified in the short-run policy directives. The Committee issues these directives to the Manager of the Open Market Account at the Federal Reserve Bank of New York.

At each meeting in 1981, the Committee specified short-run growth rates for shift-adjusted $M \perp B$ and M2.17 It also specified an intermeeting range for the federal funds rate. ${ }^{18}$ These ranges and the actual

\footnotetext{
${ }^{7} \mathrm{~A}$ short-rum growth rate target for M1A was established at the February meeting; however, MIA was dropped from the Committee's shortrmo objectives at the March neeting. The shortrun target range for MI set at the Febriary neeting was $5-6$ percent,
}

IsIf novements of the federal funds rate within the ange appear federal funds rate are presented in chart 3. The growth rates for the monetary aggregates and the ranges for the federal funds rate that the Committee specified during 1981 are presented in table 3 . Charts 4 and 5 show the short-run ranges for shift-

to be inconsistent with short-rum objectives for the monetary aggregates and related reserve paths during the intermeeting period, the manager for Domestic Operations at the Federal Reserve Bank of New York is to promptly notify the Chamman, who in turn decides whether the situaten alls for smple mentary instructions from the Committee. "Fo such meetings were called during 1981 . Meetings were called on Febuary 24 and May 6; see "Recorf" (April 1981), p. 318 and "Record" (Tune 1981), pp. 502-03. The federal fund:s rate range first appeared as at "trigger mechimesm" with the change to reserve targeting procedure on October 6, 1979. See "Record" (December 19793 , p. $97 \%$. 
Table 3

FomC Operating Ranges - 1981

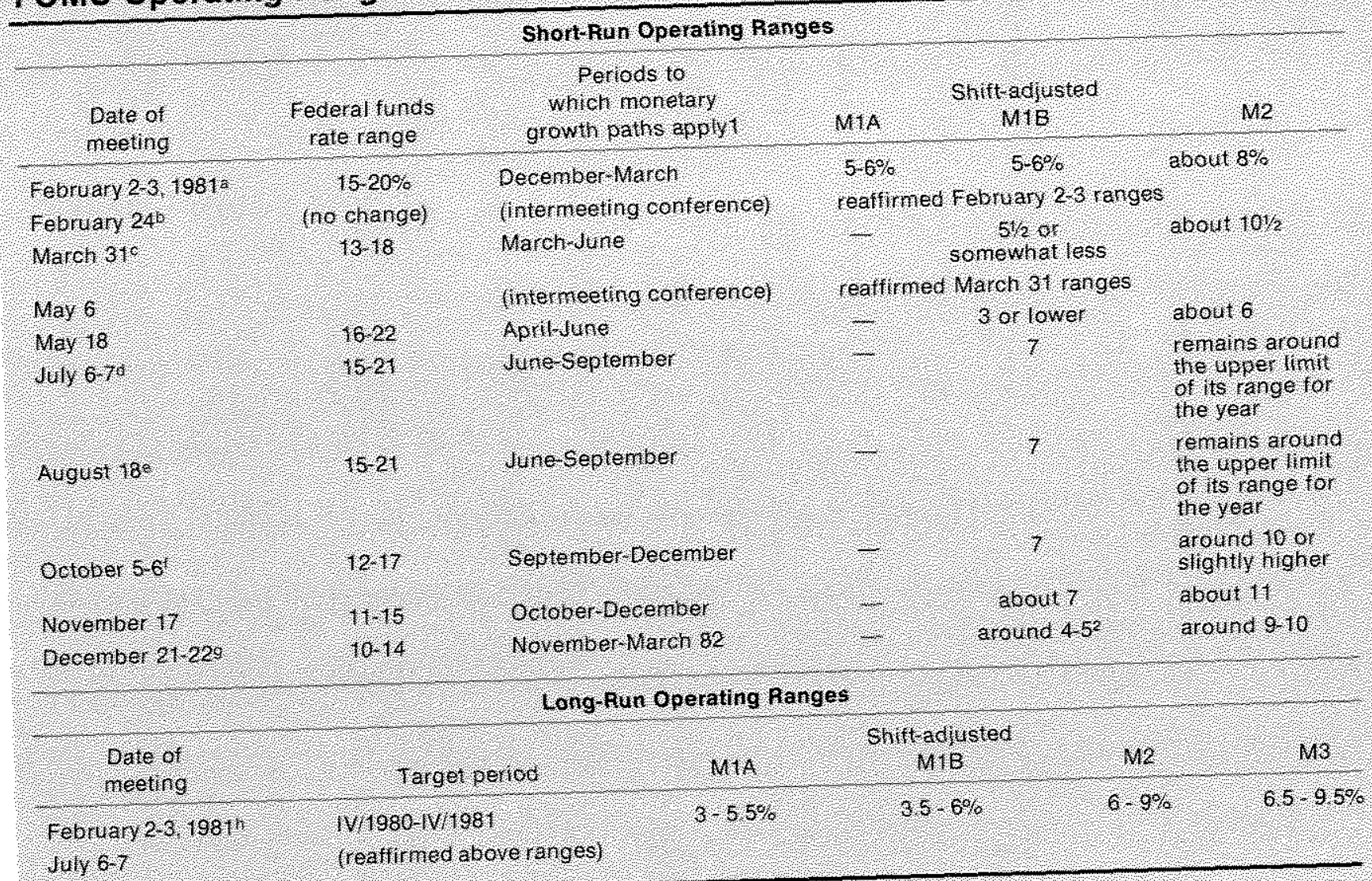

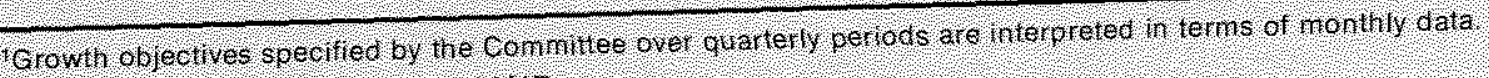

This ratge ls tor hon shit rousted Wib.

adjusted MIB and $M 2$ based on first-published data. First-published data give a more accurate representation of the Committee's short-run policy decisions based on information avalable at the time. Revised data for shiftadjusted M1B are lower relative to its annual ranges than first-published data. Revised data for $\mathrm{M} 2$ are substantially higher relative to its annual ranges than first-published $\operatorname{data}^{19}$

The Committee's short-run policy directives

9T o see this, compare charts 1 and 4 , and charts 2 and 5 . The data for $\mathrm{V} 2$ in chat 5 is higher than the M2 data as of the February tos? in this difference is due to the redefinition of $\mathrm{M} 2$ to include retail hPs (hose issued in amounts of less than $\$ 100,000$ and to exclade "institution only" MMMFs flam Bumd"s H.6 release of Felunary 5,1982 , for detaits. followed three phases and are reflected by the general movement of the monetary aggregates during the year. During the first phase, the Commit tee's objective was to achieve a gradual acceleration in the growth of shift-adjusted MIB within its amnal range, after it fell below the lower end of its range in fanuary. During the second phase, the Committee gave greater weight to keeping the growth of $\mathrm{M} 2$ around the top of or within its annual range, while permitting growth in shift-adjusted MIB to fall substantially below the lower bound of its range. In the final phase, the Committee once agitin desired more rapid growth in shift-adjusted M1B, while accepting a somewhat larger departure of $\mathrm{M} 2$ above the apper limit of its annual range. Growth rates of shift adjusted M1B, measured M1B, M2 and the adjusted monetary base corresponding to these phases are presented in table 4. 


\section{Table 3 (continued) \\ Footnotes - Dissents to FOMC Actions}

a Mrs Teeters dissented from this action because she belleved that the specificat tons adopted for monetary grow th over the first quarter were und wh restrictive She preterred specfication of higher ates tor honetary growth over the frst querter consistent with the ranges adopted for honetary growth over the whole year, in association with a lower ntermeeting range for the federal tunds rate.

Mr Wallich dissented trom this action because he preferred to seta higher ange for the federal funds rate in order to he p aveld a repetition of the sharp drop ninterest that had oceutred ho the second quarter of 1980

BM Roos dissented fom this acton because he belleved that it would tend to prolong unduly he shortall horowth of MtA and MT from the Commitees sanges for the year h the cheumstances, he prefer red to reduce the lowe linit of the intermeeting

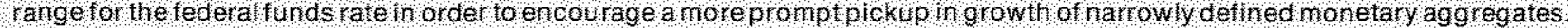

Mr. Walleh dissented from this action because he favored specification of lower nonetary orow th ates tom he period from March to June than those adopted ar his neeting along with a higher intermeeting ange for the federal funds rate ln loht of the: recent streng h of economic actwty he belleved pollcy had hot been as restrectve as supposed in part because money harket nutual tunds and other sources of liquidty had contributed to an recrease in the veloctly of MTB and hat conthuation of excessive strength $h$ actuty posed the greater danger for the pertod ahead

QMr Partee dissented from this action because h the light of weakentho n economic act wity he preterred to give more enphasis to reduche he rish of a cumulative shortfall in growth of MIB. Accordingly he favored specification of a somewhat higher object the for growth of M L over the period of une to september and without additional weight assigned to the potential for hore rapid arowh of M2 h his vew the shot thun behavior of V2 was subject to great uncertainty because of both the volathle

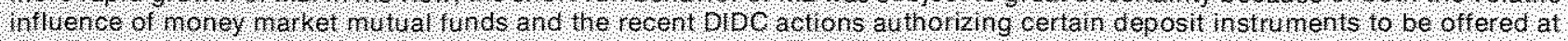
competive interest ates begnning August

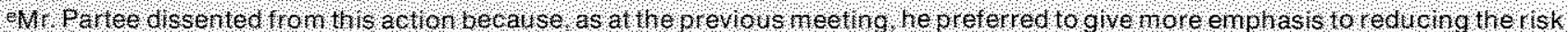

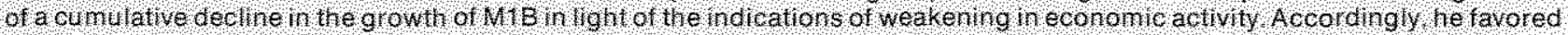
specifcation of a somewhat highel objective for growth of WUB over he period from June to september and without the

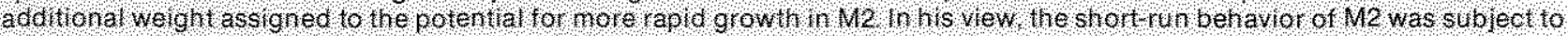

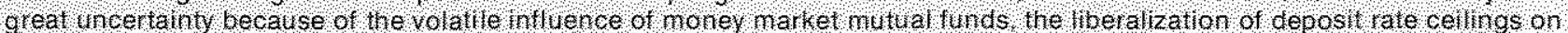

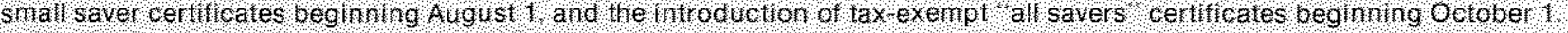

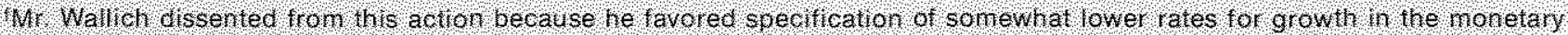

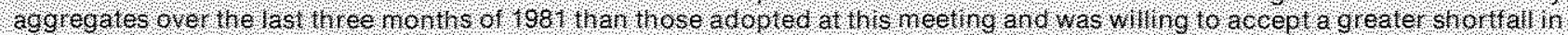

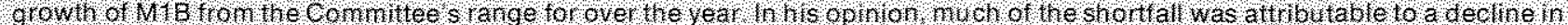

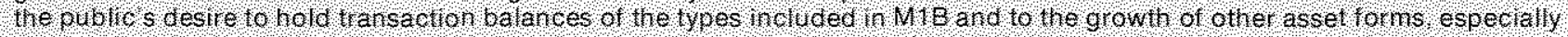
money markel nulual unds that 10 some extent serve as transaction balatces. He was also concerned that the public hioht

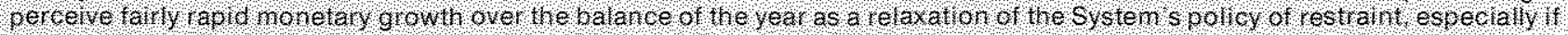
such growth were to be accompanled by sizable deereases in interest rates.

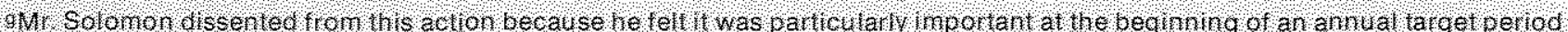

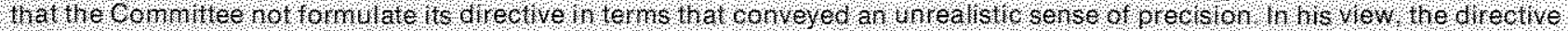

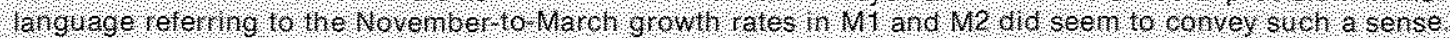

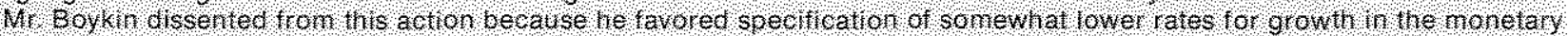

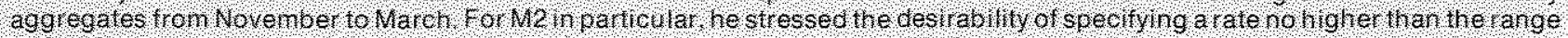

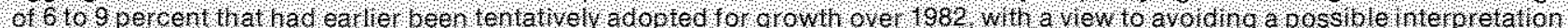

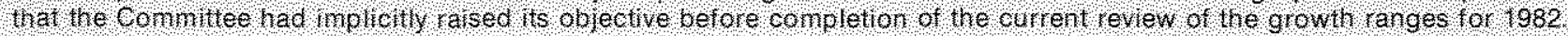

Wh Walloh dissented tron his action beeause he thought the wahges adopted for growth of Wha and Wh were too high 4 e

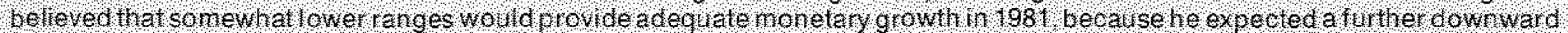
stift it money demand and also beeauso growth of the monetary agoregates over the past year generaly had exceeded he: specified anges.

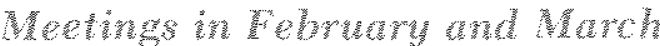

The first phase enconpasses the FOMC's first two meetings in February and March. In detemining short-run policy objectives at the February meeting, the Committee took special note of the fact that the grow th of shift-adjusted MLB, from the fourth quarter of 1980 to January 1981, had Gallen below the lower end of its annual range. It was generally agreed that open market operations, before the March meet- ing, should be directed toward agradual restoration of the growth in shift-adjusted MIB to a rate consistent with its annual range. While there was disagreement over the acceptable amount of growth during the intermeeting period, it was agreed that the gradual approach lessened the danger of misinterpreting policy intentions.

In accepting the gradual approach toward encouraging rites of monetary growth consistent with the ranges adopted for $198 \mathrm{I}$ several mombers com- 


\section{Chori 4 \\ Short-Term and Long-Term Growth Objectives for Shift-Adjusted M1B Based on First-Published Data}

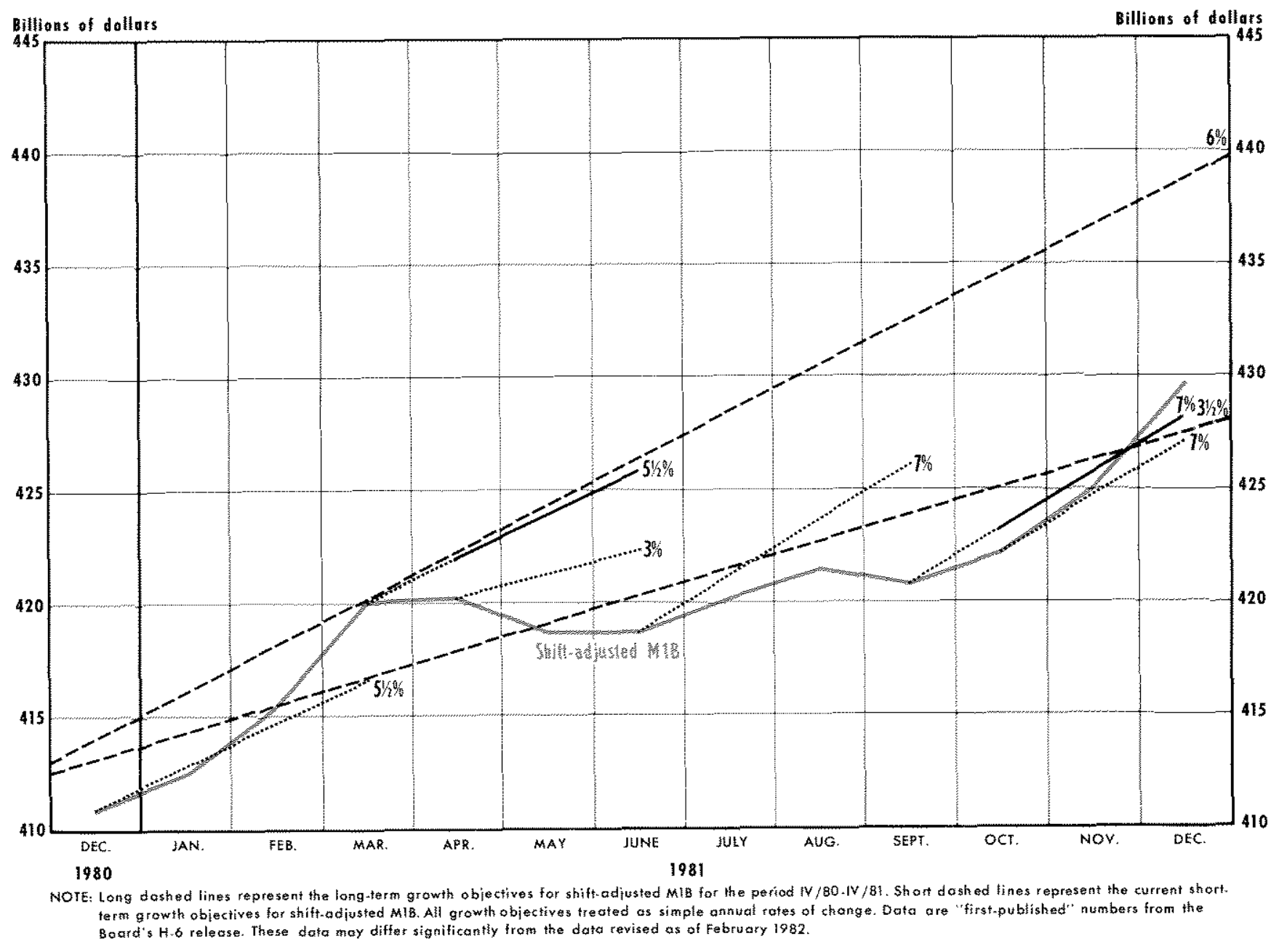

mented on the danger of potentially confusing interpretations of policy intentions and also of possible instability in financial markets. It was observed, for example, that efforts to raise monetary growth promptly toward the longer-run paths could have the indesirable consequences of encoumging first relatively rapid growth and then an abrupt decleration. A few members also suggested that the gradual approack to making up the shortfall would be acceptable provided that it proved to be compatible with relative stability or some easing in money market pressures, ${ }^{20}$

At the March meeting, it was noted that the growth of shift-adjusted M1B had expanded substantially during the first two weeks in March, but remained at a level below the bottom end of its annual range. It was also reported that the growth of M2 had ap-

$20^{\prime \prime}$ Rerord" (April 1981), pp, 316-17. parently accelerated considerably in March, spurted on by a record expansion in money market mutual funds that had more than offset the weakness in small savings and time deposits. It was argued that the weakness in the growth of shift-adjusted MIB might be a misleading indicator of the growth of transactions balances, since a part of the rapidly growing money market mutual funds might themselves be considered transactions balances. As a result of this discussion, the Committee decided to give more weight than before to $\mathrm{M2}$ in interpreting its shortrun policy directives. ${ }^{21}$

$21^{22}$ Record" (Jume 1981), pp. 500-01. Many MMMFs bave checkwitimg privileges. However, most require checks to be written in amounts of $\$ 500$ or more. For an analytical argument why MMMF deposits should not be considered money, see $R$. W. Hafer, "Much Ado about M2," this Revieu (October 1981). pp. $13-18$. 
Short-Term and Long-Term Growth Objective for M2 Based on First-Published Data

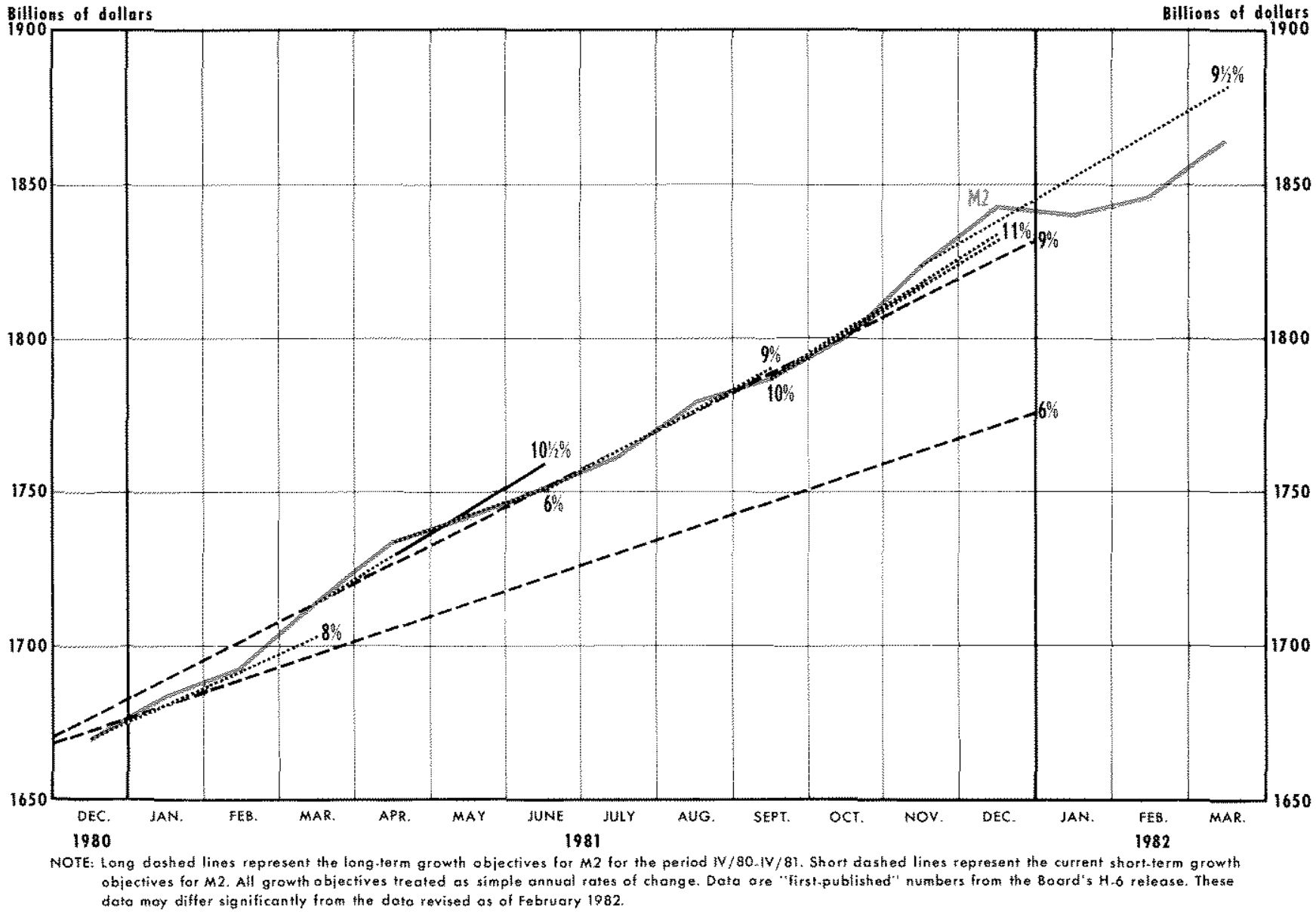

The Committee established a short-run growth rate for shift-adjusted MIB for the period March to June of " $51 / 2$ percent or somewhat less," and for M2 of "about $10 \frac{1}{2}$ percent," some $2 \frac{1}{2}$ percentage points above the range established in February. ${ }^{22}$

If achieved, these short-run growth rates would have resulted in a level of shift-adjusted MIB at the upper bound of its annual target and of M2 above the upper bound of its annual target, as illustrated in charts 4 and 5 . Thus, the Committee raised the shortrun target growth rate for $\mathrm{M} 2$ and simultaneously gave more weight to $\mathrm{M} 2$ in evaluating the behavior of the monetary aggregates.

\footnotetext{
${ }^{22}$ The disparty in the changes in these rate ranges for shift adjusted $M 1 B$ and $M 2$ is even more pronounced when "base drift is taken into consideration." On March 31, shiftadisusted MIB was at a level below the lower end of its amual range, while $M 2$ was above the upper end of its annual range.
}

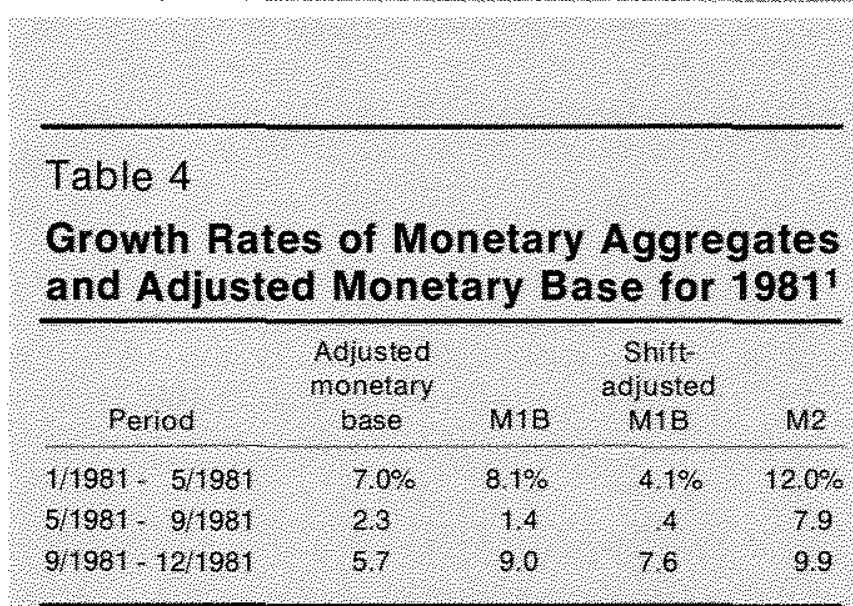

Data revised by Board of Goverrors, february 1982 


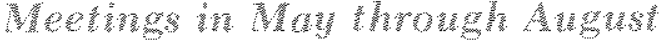

The second phase of short-run policy directives encompasses the May through August meetings. Its beginning is marked by a reversal of the policy of gradually accelerating growth of sh ift-adjusted M1B, which was characteristic of the February and March meetings. At the May meeting, the Committee noted that the growth of the monetary aggregates had been very rapid during March and April. The Board staff told the Committee that the growth of shift-adjusted M1B during May and June would have to be negligible if the growth rates specified in March were to be achieved. ${ }^{23}$ However, the staffs analysis indicated that the growth of $\mathrm{M} 2$ in the coming months would be less rapid, reflecting a slowing in the growth of savings and small-denomination time deposits and a weakness in the growth of MMMFs. It was reported that the broader monetary aggregates might move back toward the tops of their annual target ranges.

The Committee took particular note of the continuing strength of economic activity in the first quarter, the rise in income velocity of $M 1 B$, which it believed posed the risk of pressure for further expansion of money and credit later in the year, and the continuing strength of inflation expectations in deciding to reduce the growth of the monetary aggregates rather quickly. ${ }^{24}$ The Committee voted for a substantial deceleration in the growth of the monetary aggregates. The target rates of growth of shiftadjusted MIB and $M 2$ were reduced to " 3 percent or lower" and "about 6 percent," respectively, for the two-month period from April to June.

By the July meeting, the Committee noted that the rapid deceleration in the growth rates of the monetary aggregates that it had voted for in May had materialized. It was reported that the growth rate of M2 was reduced to about 5 percent for the May and June periods and that shift-adjusted M1B declined at annual rates of 5 percent in May and $10 \% / 2$ percent in June, following a grow th rate of almost 17 percent in April. This brought the growth rate of shiftadjusted MIB to about $2 / 4$ percent from the fourth quarter of 1980 to the second quarter of 1981, over

\footnotetext{
29' Record" (July 1981), p. 568.

24 The Committe anticipated that the large bulge in the income velocify of $M 1 B$ would reverse itself later in the vear, resuling in a significant increase in the demand for $\mathrm{M} B \mathrm{~B}$ and a correspondingly large inerease in the level of MlB later. See "Record" (July 1981), p. 568; "Record" (June 1981), p. 500; ard "lecord" (September 1981), p.715.
}

1 percentage point below the lower end of the annual range. ${ }^{25}$ At the same time, it was noted that the shortfall in the rate of growth of shift-adjusted MIB was accompanied by an unusually large increase in its income velocity. The significance of the relative growth of shiftadjusted $M \perp B$ and $M 2$ was considered once again.

The shortall in growth of shiftadjusted $\mathrm{MIB}$ in the first half of the year followed relatively rapid srowth in the latter part of 1980 ; and it was accompaned by an usually rapid rise in the inoone velocity of money, as nominal GNP expanded strongly. In patial explanation, extraordinarily high interest rates in combination with the introduction of NOW accounts on a nationwide basis apparently provided a greater stimulus to intensive management of cash balances than that nomally associated with an increase in interest rates. In the period ahead, MIB might behave somewhat differently from earlier measures of transaction balances, because of the sizable volume of deposits eaming interest and because of the greater weight of household balances in the total. The behavior of $M 2$ was likely to be affected to some extent by two recent decisions of the Deposi tory Institutions Deregulation Committee (DNDC), effective Alugust 1: one removed rate caps on the $2 / 2$-year small saver certificate, enabling the rate to fluctuate with the yield on $21 / 2$ year Treasury securities at all levels; and the other elminated ceilings al together on small time cleposits with initial maturities of four years or more. The rapid growth of money market funds appeared to influence the growth of both $\mathrm{Ml}$ and $\mathrm{M} 2$, in opposite directions, but the magnitude of the effects was difficult to judge.26

At the conclusion of this discussion, the Committee decided to foster the growth of shift-adjusted MIB over the third quarter that would be fast enough to push the growth of this aggregate toward the lower end of its annual range. Accordingly, the Committee adopted the following short-run policy directive.

In the short run the Committee seeks behavion of reserve aggregates consistent with growth of MIB from lune to September at an anmual rate of 7 percent after al lowance for the mact of lows into NOW ac: counts (resulting in growth at an annmal rate of about 2 percent from the average in the second quarter to the average in the third quarter), provided that crowth of he remains around the upere limit of or mowes whthin, its range for the year (talios added). ${ }^{27}$

The Committee established a growth rate for shiftadjusted M1B that, if achieved, would result in a level of shift-adjusted MIB just above the lower end of its annual range. This policy directive was reaf-

\footnotetext{
25"Record" (September 1981), p. 713.

261Hid, p. 715 .

27bie., p. 718 .
} 
firmed at the August meeting, ${ }^{28}$ However, even this growth path was conditional on the M2 proviso, that is, on M2 remaining about or moving within its annual growth rate range.

By the August meeting, the Committee was concerned that new legislative and regulatory changes were likely to alter the relative growth paths of shiftadjusted M1B and M2 still further. In particular, it expressed uncertainty about the effect of the liberalization of interest rate ceilings on small-savers certificates and the then-pending introduction of taxexempt All-Savers Certificates. ${ }^{20}$ It was thought that these developments, especially the All-Savers Certificates, might contribute to a marked acceleration in the growth of $\mathrm{M} 2$ during the fourth quarter of the year. ${ }^{30}$ Several Committee members expressed concem about relying too much on $M 2$ in view of the potential sources of distortion. At the end of this discussion, the Committee reiterated the short-run objectives it had agreed upon at its July meeting.

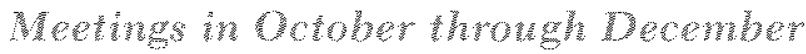

At the October meeting, the Committee took particular note of the widening divergence in the behavior of shift-adjusted MIB and the broader monetary aggregates. It continued to express uncertainty about the impact of the recent legislative and regulatory changes on the relative growth paths of the monetary aggregates. Moreover, it noted that the public's desire to hold transactions balanees in forms included in MIB apparently had declined. This was evidenced by the unusually high level of MiB velocity, given interest rate levels. While the Committee generally agreed to seek more rapid growth in shift-adjusted M1B, it disagreed about how much more growth was appropriate and how the aggregates should be weighted.

Committee nembers agreed on the desirability of continuing to seek more rapid growth in MIB over the remaining three months of 1981, while taking accont of the relative strength of the broader aggregates. The observation was made that a pickup in

\footnotetext{
28"Recora" (October 1981), p. 794.

${ }^{29}$ See "Record" (Otober 1981), p. 792. The Depository Institutions Deregulation Committee (DIDC) removed the interest rate "caps" on 30-month small-savers certificates effective Augnst 1,1981 . The interest ate cellings on small-savers certificates was allowed to fluctuate with the rate on 30 -month Treastury securities. Prior to Alagast 1 , the caps were 11.75 percent for commercial banks and 12,00 percent for thrift institutions. The DIDC also approved the introdiction of tax-exempt AllSivers Centificates effective October 1, 1981.

30"Record" (October 1981), pi. 792-93.
}

growth of MIB now would reduce the risks of cumulative contraction in activity, which could well be followed by an excessively rapid recovery and expansion.

At the same time, many members expressed the view that very rapid growth of MAB over the few remaining months of the year would contribute to instability and would interfere with achievement of longer-term economic goals. Specifically, such growth most likely would dissipate the gains already made in moderating inflation, exacerbate inflationary expectations, and induce a rebound in interest rates after no more than a tempotary dectine. Moreover, rapid growth in M1B would significantly increase the risk that the broader monetary aggregates would exceed their ranges for growth over the year by sizable margins, which was a source of concern in light of the uncertainties about the interpretation of the various monetary aggregates in the carrent circumstinces. ${ }^{31}$

At the end of this discussion, the Committee decided to give approximately equal weight to shiftadjusted $M 1 B$ and $M 2$ in developing short-run policy directives, and voted for more rapid growth in M2. This marked the beginning of the third phase in policy. The growth rate for M2 was established at " 10 percent or slightly higher," at least 1 pereentige point above the rate established by the M2 proviso of the previous two meetings. In contrast, the Committee established a growth rate of 7 percent for shift-adjusted MIB for the fourth quarter of 1981 , the same short-run grow th rate it had established for the third quarter.

By the November meeting, the Committee acknowledged that the downward drift in economic activity, which it had noted at the previous meeting, had developed into a recession. It also acknowledged that there was a modest shortfall in the growth of shift-adjusted M1B from the 7 percent rate that the Committee had established in October. Committee members continued to agree on the desirability of seeking somewhat more rapid growth in shift-adjusted MIB and reaffimed their October growth path for the narrower aggregate. The growth path for M2, however, was increased to "around 11 percent," despite the fact that M2 was above the upper end of its annual range. Furthermore, it was understood that a faster growth of shift-adjusted M1B than specified in the short-run objective was acceptable.

It was understood that somewhat more rapid growth of MIB, consistent with the objective for

a" "Record" (December 1981), pp. 908-09. 
growth over the fourth quarter adopted at the previous meeting, would be accepted in the event that transaction demands for money proved to be stronger than anticipated; it was also understood that moderate shortfalls from the growth path would not be unacceptable, particularly if broader aggregates continued to expand mapidly, 32

At the December meeting, the Committee noted that the growth of both shift-adjusted M1B and M2 had accelerated during November, reflecting the growth of other checkable deposits and the nontransactions components of M2. The Committee continued to express uncertainty about the interpretation of the monetary aggregates.

In the near-term pursuit of the fundamental objective of fostering the financial conditions that would help to reduce inflation and promote recovery in economic activity on a sastainable basis, the Committee contimued to face considerable uncertainty about the interpretation of the behavior of the monetary aggregates. Growth of other checkable deposits (OCD) had picked up sharply in November and early December. (Sach deposits include NOW accounts and ATS accomnts at banks and thrift institutions and credit union share draft accounts.) Moreover, the surge in OCD was accompanied by a renewal of flows into savings deposits at commercial banks and continuation of substantial flows into money market mutual funds, which rased growth of M2 in November to the highest rate so far in 1981. Given the volatility of the behavior of the monetary aggregates in the short run, it seemed that the recent spurt might have resulted partly from an expansion of highly liquid precautionary balances at a time of considerable uncertainty about near-term economic and financial conditions, ats well as a response to the lower level of market interest rates in earlier weeks. ${ }^{33}$

After considerable discussion over the appropriate growth rates for the aggregates, the Committee decided to set target ranges for the period November 1981 to March 1982 of "4 to 5 percent" for M1 (previously measured M1B) and "around 9 to 10 percent" for M2. If achieved, this growth of M2 would produce a level of M2 in March 1982 above a

\footnotetext{
32"Record" (January 1982), p. 42.

as" "Record" (February 1982), p. 108.
}

projection of the 11 percent growth rate that the FOMC had voted for at the November meeting. Thus, the apparent reduction in the desired growth rate of $\mathrm{M} 2$ is really more expansive when "benchmarked" at the November level of M2 (see chart 5).

\section{CONCWUSTS}

During 1981, the Federal Reserve achieved a substantial reduction in the rate of growth of M $1 B$ (both shift-adjusted and unadjusted). In fact, shift-adjusted M1B grew at a rate substantially below the lower bound of its target range for the year. In contrast, the growth rates of the broader monetary aggregates were more rapid than a year earlier.

Monetary policy decisions in 1981 reflect the Committee's commitment to restrain the growth of the monetary aggregates. However, uncertainty about the effect of financial developments on the growth rates of shift-adjusted $\mathrm{M} 1 \mathrm{~B}$ and $\mathrm{M} 2$ and on the relationship between these aggregates and economic activity led to uncertainty about which aggregate is most important to control. As a result, the FOMC twice changed its weighting of shift-adjusted M1B and M2 for the purpose of implementing its shortrun policy directives. During most of the year, the Committee allowed shift-adjusted M1B to grow below the bottom of its annual target range when $\mathrm{M} 2$ grew within or at the top of its range. In the fourth quarter of the year, M2 was permitted to exceed the top of its annual range when the Committee increased the prionity for a faster grow th of the narrower aggregate in response to declining economic activity.

Thus, it appears that the most significant question for monetary policymakers in 1981 was which monetary aggregate to control in a financial environment marked by innovation and regulatory change. The impact of such developments on the growth rates of the monetary aggregates, and the relationship between the aggregates and economic performance will undoubtedly be significant policy issues in 1982. 


\section{Appendix: Summary of Discussion at Committee Meetings}

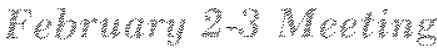

In their discussion of the economic outlook and situation during this meeting, Committee members disagreed on the expected path of real output and unemployment for 1981. However, all members anticipated a some what higher inflation rate for 1981 .

At this meeting, the Committee completed a review of the long-term grow th rates of the monetary aggregates for the period from the fourth quarter of 1980 to the fourth quarter of 1981 , as mandated by the Full Employment and Balanced Growth Act of 1978. This discussion began at the December 1980 meeting. Members of the Committee agreed that, in light of their long-standing goals of contributing to a reduction in inflation and providing a basis for the restoration of economic stability and growth in real output, a further reduction in the ranges for monetary growth was appropriate. However, there was concem that the impact of the nationwide introduction of NOW accounts on December 31, 1980, as authorized under the Monetary Control Act of 1980 , had changed the relationships among the measured growth rates of the monetary aggregates.

It had been anticipated that shifts into NOW accounts would significantly reduce the growth in M1A and enhance the growth of MIB. However, the experience during the first few weeks in January revealed much larger shifts than anticipated. It was generally concluded that estimates of the impact of such shifts on the measured growth rates of the two monetary aggregates could be only tentative due to the size of and uncertainty about the ultimate source of the funds. Nevertheless, the Committee, abstracting from the NOW account effects, specified ranges for $\mathrm{M} 1 \mathrm{~A}$ and $\mathrm{M} 1 \mathrm{~B}$, one-half percentage point below the 1980 ranges. While the members differed somewhat more in their views about the growth rates for the broader monetary aggregates, the Committee

\footnotetext{
Note: Citations to "Record of Policy Actions of the Federal Open Market Committee" are referred to as "Record." Money growth rates referred to in this appendix are taken from published nin utes of the Committee's meetings for 1981 and therefore, may not correspond to more recent benchmark revisions. The data reflect information avalable to the Committee at the time of the meetings.
}

ultimately decided to maintain the 1980 longuterm growth rates for $\mathrm{M} 2$ and $\mathrm{M} 3$ and conmercial bank credit in 1981.

Considering the objectives for monetary growth for the intermeeting period, the Committee took particular note of the fact that both MIA and $\mathrm{M} 1 \mathrm{~B}$ had fallen below their 1981 growth paths during the December-January period. It was generally agreed that open market operations should be directed toward a gradual restoration of the growth in M1A and $M \perp B$, adjusted for NOW account effects. Almost all members were willing to accept the continuation of relatively slow growth in relation to the ranges for 1981 , at least through March, in recognition that it would generally compensate for the rapid growth during the fourth quarter of 1980 , which carried growth for the year slightly above the upper bounds of the ranges.

Thus, the Committee decided to seek growth rates in MIA and M1B that would gradually bring these aggregates within their annual target ranges, with the provision that the Chamman would be notified if a range for the federal funds rate of 15 to 20 percent appeared to be inconsistent with the monetary and related reserve paths.

Late in February, data on MIA and MIB, after adjusting for NOW account shifts, indicated these aggregates were growing at rates well below those consistent with the policy directive. Simultaneous$\mathrm{ly}$, the grow th in $\mathrm{M} 2$ and $\mathrm{M} 3$ was stronger than anticipated. Also, the federal funds rate had declined to around the 15 percent level. As a result of a telephone conference on February 24, the Committee adopted the following modification to its earlier policy directive:

In light of the relatively strong growth of $\mathrm{M} 2$ and $\mathrm{M} 3$ and the substantal easing recently in money market conditions, as well as uncertainties about the interpretation of the behavior of $M 1$, the Committee on February 24 agreed to accept some shortfall in growth of MLA and MIB from the specified rates in the domestic policy directive achopted on February 3 as consistent with developments in the aggregates generally and the objectives for the year,

\footnotetext{
$\overline{1 . " R e c o r d " ~(A p r i l ~ 1981), ~ p . ~} 318$.
} 


\section{Organization of the Committee in 1981}

The Federi Open Wratet Commented (FOMO) oon sists of 12 nembers the reven me mbers of he Federal heserte Boand of Gowenors and hve of the 12 Federal Reserve Banl, restants The Clamnan of the Board of Covennors 1s by hadition, $1 \mathrm{ko}$ dhaman of he Com mittee The president of the New Jonl Federal Teserve Bank to aso by tradition, is s rce chamman $\mathrm{Al}$ Eederal hesene Bank presidents attend Cemmuttee meetngs and nresent their hess, but only those presidents who ate nenbers of the Committee hay cast votes. Fou nembershins rotale anong Bank prestents and are held for one- - ear terns be gmnmg Warch 1 of each year. The president of the New Yolk Fedend Reserwe Bunk is a permanent boting nember of the Committee.

Menhers of the Bowd of Governors at the begmning

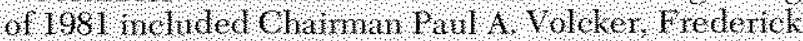

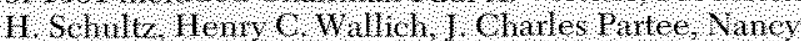

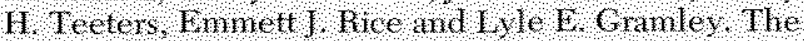
followng presidents served on he Committee funng

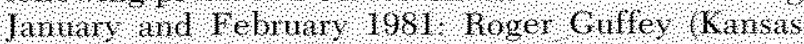
City, Frank L, Monis Boston, Lawrence K Roos (St. 1 omet and Wils 1 Winn (Cleveland) The Commitee was reorganzed in Whrch and he fon rothlimg post tions were flled by t o wand $O$ Bochne (Philadelohta) Robert H, Boykn (Oallas, I, Gerald Corrigan Whi neapols) $\mathrm{s} / \mathrm{t}, \mathrm{Ke} / \mathrm{h}$ (Cheago)

The Oommittee net eight times dung 1981 to dir. cass, thong other hing, teonomic hemds and to degle upon he tuture colnse of open harket open

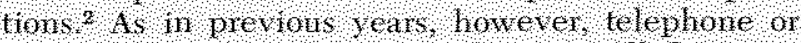
te legram consultations were held occasionall y between seheduled neet ngs Durng each regulaml scheduled neeting a directive was is sted to the Federat Reserve Bank of New Tork Fach dreetive contaned a short revew of economic developments, the general eeonomic god s songht by the Comnittee, and hnstructions to the Manager of the System Open Manet Aceonat at the Xew York Bank for the condinet of open natket openthon, These hutnuctions were stated an tems of shorttern rates of growth of MIN, shift adjusted $\mathrm{MIB}$ and M2 that were conshered to be consistent with desned longermin growth ates of the nometar ag-

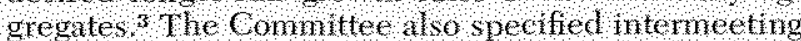
ranges for he fedent wnds ate, These anges pro ldea meehanom for hntathng consultatons hetween meetngs whene ven 1 appears that fuetuations within the specifed range 15 proving incons stent watl $t$ he objectres for the behavior of the monetary aggregates.

The Accowne Wanager has the najor responsibility for formulating plans negandhg the timing, ypes and anount of dal y bung and sel $n$ ng of secmites an ful flling the Committees drectud Hach nomming the Manager and his staff plan the open narket operations tor that day. This plan is te eloped onthe beth of the Committees directive and the latest developments af ectng noney and credit narket end hons, growth of he monetary aggregates and bank leserve cond -

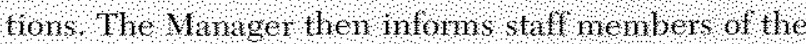
Bomd of Govenors and one toting orestdent about present narket conditions and open market opetations that he proposes to execute that day Other nembers of the Commuted are infonmed of the datly phan by wire.

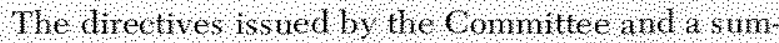

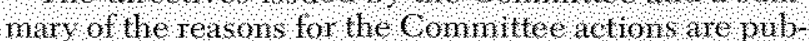
lished in the Recond of Polfc Adtons of the Federa Open Narket Commeter the Recond for facl neeting is released a few arys after lhe following Sommittee neetimg Soon after its release 4 e Ree ord appears n the Fellen ol he enve bulleth In add tron, Records toi the entire year are publis hed in the

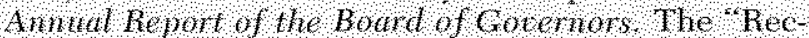
ad for each heetng duning 981 included

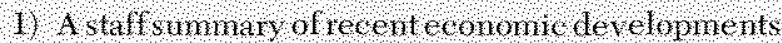

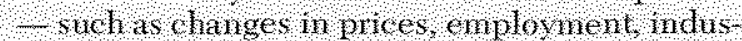
thal prod hetion, and eomponents of $\mathrm{he}$ nallond treane accounts 4 and projections of genenal

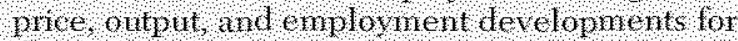
the yeathead.

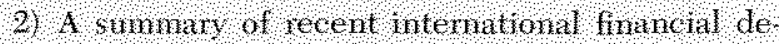
velopments and the US S foreign hade balanee;

3 A summers of tecent credit malet conditrons and recent interest rate novenents.

4 A summars of 0 pen morket operations, growth of monetars aggregates and bonk teserves, and nones warket tond tons s nee the prevtons neeting,

51 A smmar of the Committee s d s of solon of eur rent and prospective economie and finanelal conditons and of ctrrent polcy considerations. melud ne noney narket ond wons and the movemelt of monetar aggregates.

$6)$ Conclestons of the Connmitte,

$7 /$ A poliey dredtue issued by he Committee to the Federal Reserve Bank of New Yolk,

8) $\mathrm{A}$ Ist of he nembers voting pos thons and any dssentung comonents

9) Adescmpton of any act ons and ensultat ons that man have oednred between the regularly scheduled meetmgs.

Mr Keeln took offce as Presilent of the Chicago Bank on

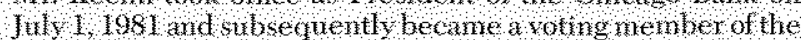
FOMC, From Ward to June, Mr W Wn voted as an altenate menther

2 No fonmit meetings were held n f fmonay, April, Jume or September of 1081

At the Mard 3 meeting of the Conmitee, shorttem growth objectues for $M$ llA were discontinued: 


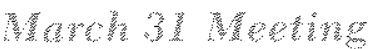

The Committee's discussion of policy for the immediate future focused on two interrelated issues: the desired vate of growth of narrowly defined money, and the appropriate weight for $\mathrm{M} 2$ in implementing policy. It was suggested that the slow rate of growth of M1B during the early months of the year might be a misleading indicator of the growth rate of transactions balances over this period. It was argued that some part of money market mutual funds might be regarded as transactions balances. Thus, the rapid growth in these funds might indicate a faster growth in transactions balances than the growth rate of measured M1B would show.

The Committee also noted that shifts into money market accounts would probably continue to distort the growth of MIB to an unpredictable extent. Thus, the Committee agreed to the following change in procedure:

In evaluating the behavior of the aggregates, it was agreed that greater weight than before would be given to the behavior of $\mathrm{M} 2 .^{2}$

On May 6, the Committee held a telephone conference. Available data showed a sharp increase in the rate of growth of $\mathrm{M} 1 \mathrm{~B}$, pushing it to about the midpoint of the $3 \frac{1}{2}$ to 6 percent range established for 1981. The growth of $\mathrm{M} 2$ had decelerated slightly in April; however, it continued to expand at a relatively rapid rate. Simultaneously, it was reported that the reserves supplied through open market operations declined substantially, putting strong pressure on banks' reserve positions. As a result, borrowings from the Federal Reserve increased sharply in late April and early May, the federal funds rate increased from 13 to 14 percent and the surcharge was increased from 3 to 4 percent, effective May 5 . Due to the short time before the next regularly scheduled meeting on May 18, the Committee agreed to maintain the short-run objectives for monetary growth established at the March 31 meeting.

\section{Why}

The staff projections presented at this meeting indicated that the sharp uptum in real GNP that occurred in the first quarter of the year would moderate over the rest of 1981 . However, a number of Committee members expressed the opinion that the expansion in economic activity over the remainder of the year was likely to exceed earlier expecta-

${ }^{2 *}$ "Record" (June 1981), p. 501 . tions. It was generally agreed that there was a need to reduce the growth rates of the monetary aggregates quickly in order to maintain a posture of monetary restraint.

In considering objectives for monetary growth over the remainder of the quarter, the members in generit agreed that a posture of restraint needed to be maintained. They generally agreed with the view that it was paticularly important to reduce growth of the monetary aggregates rather quickly, and initial differences in views conceming the precise specifications for monetary growth were relatively narrow. In the discussion a number of points were emphasized. The indications of continuing strength in economic activity combined with the recent exceptional rise in the income velocity of money posed the risk of pressure for excessive expansion in money and credit as the year developed. Growth of the broader monetary aggregates was already somewhat high relative to the Committee's ranges for the year. The indications of some slowing of the rise in the consumer price index did not appear to reffect as yet any dear relaxation of underlying inflationary pressures, and emphasis was placed on the importance of conveying a clear sense of restraint at a cutical time with respect to inflation and inflationary expectations. ${ }^{3}$

Thus, the Committee reduced the short-run growth rate ranges rather sharply from the levels established at the March 31 meeting.

In the short rum the Committee seeks behavior of reserve aggregates consistent with a substantial deceleration of growth in $\mathrm{M} 1 \mathrm{~B}$ from April to Jume to an ammat rate of 3 percent or lower, after allowance for the impact of flows into NOW accounts, and with growth in $\mathrm{M} 2$ at an ammal rate of about 6 percent. The shortfall in growth of M $1 B$ from the two-month rate specified above would be acceptable, in light of the rapid growth in April and the objective adopted by the Committee on March 31 for growth from March to 1 une at an anmal rate of $51 / 2$ percent on somewhat less. ${ }^{4}$

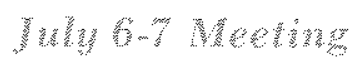

In accordance with the provisions of the Full Employment and Balanced Growth Act of 1978, the Committee reconsidered its long-term growth ranges for the monetary aggregates from the fourth quarter 1980 to the fourth quarter 1981 and gave preliminary consideration to its long-run ranges for the fourth quarter 1981 to the fourth quarter 1982. It eited the recent unexpected strength in the economy and the need to reduce the rate of inflation as the primary considerations that influenced its choice of long-run ranges.

\footnotetext{
3"Record" (July 1981), p. 568 .

4bid., p. 569 .
} 
In the Committee's discission of the longer-run ranges, the members were in agreement on the need to matintain a policy of restraint. However, continuation of the increase in velocity of $\mathrm{M} 1 \mathrm{~B}$ at the rate of the first half seemed unlikely, and thus the public's demand for narrowly defined money would probably pick ap in the second half. Moreover a significantly more rapid increase in narrowly defined money would be necessary to reach the Committee's objective for the year. At the same time, it was observed that the present situation provided a critical opportunity to sustain the signs of progress in reducing the rate of inflation, an opportunity that could be lost if monetary growth in the months ahead became too rapid. Even if rapid monetary expansion should lower interest rates, which was debatable, sach effects would likely be temporary, and latent demands for goods and services would be released at the potential cost of a still more diffeult period of high interest rates and financial stratiss later. The point was made that lasting dectines in nominal interest rates and a solid base for sustained growth would depend on convincing progress in reducing inflation. ${ }^{5}$

In reaffiming the fourth quarter 1980 to fourth quarter 1981 growth rate ranges for the monetary aggregates established during the February meet ing, the Committee expected that the growth in M1B for the year would be near the lower end of its annual range, while growth in the broader monetary aggregates might be high in their ranges. ${ }^{6}$

In the Committee's discussions of policy for the short rum, it argued for faster growth in M1B, that would pernit third-quarter growth in this aggregate toward the lower end of its range for the year.

However, the Committee wanted to be cautious, avoiding too rapid a rebound in M1B. It was argued that too rapid expansion in $M 1 B$ would need to be sharply reduced later and might tend to raise the growth in M2 above the upper end of its target range for the year. Thus, the Committee introduced the following $\mathrm{M} 2$ proviso into its domestic policy directive.

In the short ran the Committee seeks behavior of reserve aggregates consistent with growth of M1B from June to September at an annual rate of 7 percent after allowance for the impact of flows in to NOW accomts (resulting ir growth at an annual rate of about 2 percent from the average in the second guarter to the average in the third quarter), provided that growth of $\mathrm{M} 2$ remains around the upher limit of or moves within, its range for the year (italkes added) ?

\footnotetext{
s"Reoord" (September 1981), pp. 715-16.

slbid., p. 716 .

Thid, p. 718 .
}

A

In discussion of policy for the immediate future, the Committee engaged in a lengthy discussion of the impact of financial developments on the grow th paths of the monetary aggregates. In particular, the impact of recent legislation and regulatory developments on the growth rate of $\mathrm{M} 2$ was questioned.

\begin{abstract}
Among the uncertainties in question were the further impact on $\mathrm{M} 2$ of the liberalization of interest rate ceilings on small saver certificates, the continuing attractiveness of money market mutual funds, and the extent to which payments to stockholders as a result of recent merger activities were being invested in nontransaction-type accounts included in $\mathrm{M} 2$. Even more difficult to assess was the impact of the introduction of tax exempt "all saver" certificates on October 1, 1981; those centificates could well con" tribute to a marked acceleration in $\mathrm{M} 2$ growth during the fourth quarter, but in the interm measured M2 might be artificially lowered to the extent that funds earmaked for investment in these new instruments were being temporatily accmulated in repurchase agreements with October I maturities. ${ }^{8}$
\end{abstract}

The view was expressed that, because of the increasing difficulty in interpreting the performance of the monetary aggregates, one might argue that more weight should be given to interest rates in evaluating monetary policy. However, it was argued that an attempt to stabilize or reduce interest rates might be counterproductive if it forced excessive monetary expansion and then encouraged inflation expectations. Some members of the Committee had expressed the belie that there were signs that inflation expectations were beginning to abate. Several members expressed concern about placing too much emphasis on $\mathrm{M} 2$, given the potential sources of distortion of this aggregate. Nevertheless, the Committee's short-run domestic policy directive contained an $\mathrm{M} 2$ proviso.

In the short run the Committee continues to seek behavior of reserve aggregates consistent with growth of $\mathrm{M} 1 \mathrm{~B}$ from June to September at an anmual rate of 7 percent after allowance for the impact of flows into NOW acconnts fresulting in growth at an anmul rate of about 2 percent from the average in the second cuarter to the average in the third quarter), protided that growth of M2 rematis around the upper limit of or moves within its range for the year (italics added) ${ }^{\prime}$

\footnotetext{
4c Record" (October 1981), p. 792.

${ }^{9}$ ibid., p, 794 .
} 
Much of the discussion at this meeting centered on concerns over the appropriate weighting of the monetary aggregates given their divergent growth paths. This discussion followed along lines similar to the August meeting. It was decided that equal weight would be given to movements in MIB and M2. The M2 proviso, which had first appeared in July domestic policy directive, did not appear in the policy directive for this meeting.

The Committe recognized that the behavior of that aggregate would be affected by the recent regulatory and legislative changes, paticularly the public's response to the avalability of the all savers certinate. In developing related reserve paths, approximately equal weight would be given to the movements in M1B and M2. It was understood that if these objectives were realized, growth of $\mathrm{AlB}$ from the fourth quarter of 1980 to the fourth quarter of 1981 would remain below the Committee's range for the year, while growth of $\mathrm{M} 2$ would equal or slightly exced the upper end of its range. ${ }^{10}$

There was a general consensus that real GNP was drifting downward and would likely continue to follow this general path into mid-1982. It was noted that a more rapid expansion of MIB growth would reduce the risk of a cumulative contraction in real economic activity. However, many Committee members expressed concern that too rapid expansion of $\mathrm{M} 1 \mathrm{~B}$ over the remaining months of the year might exacerbate inflation expectations, thus dissipating gains in moderating inflation made so far during the year. It was feared that this would cause interest rates to rise after no more than a temporary decline.

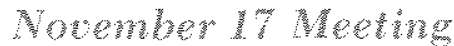

There was a general consensus among Committee members that the downward drift noted at the October meeting had developed into a recession. The weakness in the economy had begun to spread and intensify. However, it was thought that the sched uled reductions in federal income taxes, the projected increase in expenditures for national defense and falling interest rates would generate an upturn in economic activity sometime in mid-1982.

At the same time, the Committee remained concerned that inflationary tendencies remained strong. It was emphasized that inflation expectations would have a significant impact on long-term inter-

10"Record" (December 1981), p. 909. est rates and, thus, the ability of the economy to sustain a recovery. Thus, the Committee decided to pursue a somewhat more rapid growth of $\mathrm{M} 1 \mathrm{~B}$ provided the broader aggregates did not expand too rapidly.

Committee members continued to agree on the desirability of seeking somewhat more rapid growth in $M 1 B$, while taking accotnt of the relative strength of the broader monetary aggregates. At the same time, however, questions were rased about how aggres. sively more rapid growth in M B B should be pursued in the short period before the end of the year. The view was expressed that objectives for growth of MIB over that interval should take account of the desirability of a smooth transition to the targets for monetary growth tentatively established for 1982 as well as the relatively rapid growth in the broader aggregates. While recognizing the variability of demands for money over the short run, many members thought that an aggressive effort to stimulate MIB growth over November and December at a pace sufficiently rapid to compensate for the shortfall in October would interfere with achievement of longerterm economic goals and would risk overly rapid expansion of money and credit in later months, particulaty it the effort were accompanded by the precipitous decline in short-tern interest rates to levels that might not be sustainable. Such a decline in short-tem rates could exacerbate inflationary expectations and abort a desirable downtrend in bond yields and mortgage interest rates. . . It was understood that somewhat more rapid growth of M1B, consistent with the objective for growth over the fouth quarter adopted at the previous meeting, would be accepted in the event that transaction demands for money proved to be stronger than anticipated; it was also understood that moderate shortfalis from the growth path would not be unacceptable, particalarly if broader aggregates continued to expand rapidly. ${ }^{13}$

The range for the federal funds rate was narrowed to 4 percentage points, 11 to 15 percent.

\section{December $21-22$ Hecting}

In the Committee's discussion of the economic situation and outlook, the consensus was that real GNP was declining substantially in the current quarter. It was observed that the risk of further significant contraction in the automobile and housing industries appeared small. Furthermore, it was noted that the already legislated income tax reductions were likely to contribute to an upturn in economic activity by the middle of 1982 .

With respect to the monetary aggregates, it was noted that shift-adjusted MIB had expanded in

${ }^{11^{4 /}}$ Record" (January 1982), p. 41-42. 
November and early December to levels somewhat above the levels established at the previous meeting. Nevertheless, the growth of shift-adjusted M1B from the fourth quarter of 1980 to the fourth quarter of 1981 was about 2 percent, about $1 \frac{1}{2}$ percentage points below the lower end of the annual range. Growth in M2 for November was at the highest rate thus far in 1981, reflecting a surge in its non-transactions component in addition to the recent strength in M IB. Growth over the year was estimated at about $91 / 2$ percent, somewhat above the upper bound of its amnual range.

In discussing the near-tem policy objectives, the Committee noted that its fundamental objective is to foster financial conditions that would help reduce inflation and promote economic recovery on a sustainable basis. However, the Committee continued to face considerable uncertainty about the interpretation of the behavior of monetary aggregates and, therefore, the desired growth rate.

Growth of other checkable deposits (OCD) had picked up shaply november and early December. Such deposits include NOW accounts and ATS accounts at banks and thrift institutions and credit union share draft accounts.) Moveover, the surge in OCD was accompanied by a renewal of flows into savings deposits at commercial banks and continuattion of substantial fows into noney market mutual funds, which raised growth of $\mathrm{M} 2$ in November to the highest rate so far in 1981 . Given the volatility of the behavior of the monetary aggregates in the short run, it seemed that the recent spart might have resulted partly from an expansion of highly liquid precautionary balances at a time of considerable uncertainty about nearaterm economie and financial conditions, as well as a response to the lower level of market interest rates in earlier weeks.

Some members stressed the desirability of specifying growth rates for both $M 1$ and $M 2$ for the foumonth period that would be within the ranges that had been tentitively adopted for 1982 , partly with a view to avoid any possibe misunderstanding of the Committee"s objectives in the period before completion of the review of its growth ranges for 1982 . Other menbers stressed the mportance of avoiding an abrupt deceleration of monetary growth in the first quater of 1982, particularly if accompanied by upward interest rate pressures, because such developments might well hamper recovery in economic activity. A number of members were willing to accent rela tively ratid growth in the period ahead, to the extent that it reffected a continuation of the recent behavior of other checkable deposits and this might reflect expansion in its sizable savings component. ${ }^{12}$

At the conclusion of this discussion, the Committee established growth rates for $\mathrm{Ml}$ and $\mathrm{M} 2$ of 4 to 5 percent and "around 9 to 10 percent," respectively.

"22"Recore" (February 1982), p. 108.

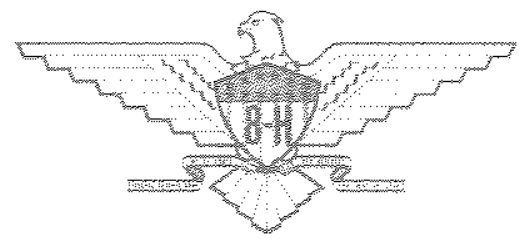

